\title{
Economic modeling of innovation ecosystems
}

\author{
Evgeny Popov $^{1}$, Victoria Simonova ${ }^{1,2}$, and Igor Chelak ${ }^{1, *}$ \\ ${ }^{1}$ Ural Institute of Management - a branch of the RANEPA, 620144, 8 Marta Str., Ekaterinburg, Russia \\ ${ }^{2}$ Institute of Economics, Ural Branch of the Russian Academy of Sciences, 620014, Moskovskaja Str., \\ Ekaterinburg, Russia
}

\begin{abstract}
Within the framework of traditional economic approaches that incline the researcher's attention to the ordering of systems, it is difficult to track and adequately assess the turbulent changes in the environment in the conditions of transformation of almost all spheres of the economy. The way out of this cognitive trap is possible in applying the tools of the ecosystem approach, which considers economic relations within a set of ecosystems as extra-organizational, self-organized forms of conducting commercial and social (non-commercial) entrepreneurship. A hierarchy of models of innovative ecosystems is proposed for scientific and practical analysis of the phenomenon under consideration and for developing recommendations for the formation of necessary conditions for the development of ecosystem relations. The combinatorics of environmental factors and internal structure allows us to construct a significant set of ecosystem models.
\end{abstract}

\section{Introduction}

The key source of development of the modern economy is innovations that are widely and systematically distributed [1]. At the same time, the high cost and risk of the innovation process force firms and related organizations (government, scientific, educational, infrastructure) to join forces in developing and promoting new products and services $[2,3]$. This kind of convergence of different players, multiplied by the capabilities of the latest communication technologies, management methods, forms of entrepreneurship, and types of interaction between stakeholders determine the deployment of innovative ecosystems [4]. This process is of great interest to scientists and practitioners, and leads to an increase in research that is developing and improving the ecosystem approach - a new method for analyzing socio-economic relations. The developed method should enrich the tools of analysts aimed at studying the deep connectivity of subjects and processes in the economic life of society, a high degree of self-organization and complexity of economic systems [5]. Improvement of this method will not be complete without developing a hierarchy of models for innovative ecosystems. The proposed hierarchy of models is an increment of knowledge in ecosystem theory.

\footnotetext{
*Corresponding author: chelak@mail.ru
} 


\section{Methods}

Based on the author's developments and content analysis of scientific sources, the article attempts to propose a hierarchy of models of innovative ecosystems as a new type of interaction in the socio-economic space. The task is complicated by the following characteristics of ecosystems: lack of borders, inclusion in one another, intersections. It is difficult to draw clear boundaries between ecosystems. Therefore, the models of innovative ecosystems proposed in the article should serve as a guide for researchers and practitioners, and not as a rigid construction.

The studied phenomenon is considered taking into account many factors that affect the features of models and components of ecosystems that have interactivity. A number of practical examples of communities of a new type are given. In general, the innovation ecosystem is modeled from the perspective of a stakeholder approach, with the justification of the importance of identifying and stratifying the main actors for studying, predicting and planning the degree of their influence on the development of ecosystem interactions and ensuring positive results.

The subject of the research is theoretical and methodological foundations for modeling innovative ecosystems. The article uses methods of system logical analysis and economic modeling.

\section{Results and Discussion}

When analyzing various ecosystems, the following models of innovative ecosystems can potentially be identified (table 1).

Table 1. Models of innovative ecosystems

\begin{tabular}{|l|l|l|}
\hline №/a & \multicolumn{1}{|c|}{ Modeling factor } & \multicolumn{1}{c|}{ Models of ecosystems } \\
\hline 1 & \multicolumn{1}{|c|}{2} & \\
\hline 1 & $\begin{array}{l}\text { Conditional boundaries and } \\
\text { scale of ecosystems }\end{array}$ & $\begin{array}{l}\text { - global } \\
\text { - trans(inter)national } \\
\text { - national } \\
\text { - interregional } \\
\text { - regional } \\
\text { - inter-municipal } \\
\text { - local } \\
\text { - intercompany } \\
\text { - intrafirm } \\
\text { - individual ecosystems }\end{array}$ \\
\hline 2 & $\begin{array}{l}\text { Source of origin and } \\
\text { regulation }\end{array}$ & $\begin{array}{l}\text { - natural (self-developing, self-regulating, self-organizing) } \\
\text { - artificial (controlled, regulated) }\end{array}$ \\
\hline 3 & $\begin{array}{l}\text { The physical nature of } \\
\text { existence }\end{array}$ & $\begin{array}{l}\text { - real (spatial) } \\
\text { - digital (cloud, virtual, quasi-real) } \\
\text { - mixed (transitive) }\end{array}$ \\
\hline 4 & The strategy of evolution & $\begin{array}{l}\text { - extensive growth ecosystems } \\
\text { - intensive growth ecosystems }\end{array}$ \\
\hline 5 & Level of openness & $\begin{array}{l}\text { - open } \\
\text { - private }\end{array}$ \\
\hline 6 & Morphology & $\begin{array}{l}\text { - holistic } \\
\text { - flexible }\end{array}$ \\
\hline
\end{tabular}


Continuation of Table 1.

\begin{tabular}{|c|c|c|}
\hline 7 & $\begin{array}{l}\text { The main sphere of social- } \\
\text { economic life (branch of the } \\
\text { economy) }\end{array}$ & $\begin{array}{l}\text { - political } \\
\text { - social } \\
\text { - economic } \\
\text { - technological } \\
\text { - financial } \\
\text { - institutional }\end{array}$ \\
\hline 8 & $\begin{array}{l}\text { The nature of the internal } \\
\text { interactions }\end{array}$ & $\begin{array}{l}\text { - regulatory (regulated, dominant) } \\
\text { - contractual (market, partner) }\end{array}$ \\
\hline 9 & Control mode & $\begin{array}{l}\text { - market-type ecosystems } \\
\text { - command-type ecosystems }\end{array}$ \\
\hline 10 & Stakeholders & $\begin{array}{l}\text { - platform ecosystem (the main stakeholders of the } \\
\text { ecosystem are numerous suppliers and consumers who can } \\
\text { interact directly with each other) [6] } \\
\text { - smart community ecosystem (consists of a public, } \\
\text { government, economic component, within the urban or } \\
\text { regional environment) [7] } \\
\text { - industry multi-actor network (the model includes firms, } \\
\text { institutions of higher education and research centers, } \\
\text { governmental and non-governmental organizations that are } \\
\text { primarily in one industry) [8,9] } \\
\text { - ecosystems with a dedicated center (University, } \\
\text { production, financial structure, etc.) [10] } \\
\text { - ecosystem of innovation developers (ecosystem model as } \\
\text { a combination of internal researchers, developers, and } \\
\text { external socio-political stakeholders [11] }\end{array}$ \\
\hline
\end{tabular}

Source: authors ' development

The features of the last, tenth type of models entail the need for additional discussion. Highlighting the importance of the stakeholder paradigm, Luciana Maines da Silva and coauthors emphasize that stakeholders are a key concept of the ecosystem approach. Stakeholders can include any group or individual that can influence the achievement of the goals of the organization or the entire ecosystem. They can be divided into internal or external groups, economic or non-economic entities. These researchers write: "The external group is composed of social and political actors who play a fundamental role in the credibility and acceptance of business activities, including governments, competitors, consumer advocates, environmentalists, special interest groups, and the media» [11, p.4].

Heiner Lütjen and co-authors complement the importance of stakeholders in ecosystem ontology by arguing that ecosystems live off the energy of dynamic capabilities of stakeholders - their ability to integrate, build and reconfigure internal and external competencies to adapt to rapidly changing conditions [1]. Among these dynamic capabilities, authors include three abilities that are important for maintaining a competitive advantage:

1) sense and shape opportunities and threats;

2) take advantage of these features;

3) maintain competitiveness by expanding and reorganizing intangible and material resources.

In terms of levels, ecosystem elements are embedded in several contexts: micro (intersubject transactions), meso (networks), and macro (social relations in a global, institutional context). Maria Vincenza Ciasullo with colleagues points out: «The ecosystems view helps identify actors, contexts and resources engaged in complex communities and allows light to be shed on stratified governance, decision- making and policy-making to capture implications and innovative outcomes at each level» [7, p. 6]. 


\section{Model examples of innovative ecosystems}

Ecosystem methodology cannot be considered an abstract theory. Below are three practical model examples of an innovation ecosystem that differ "phenotypically", externally, but have fundamental internal properties of connectivity, self-organization, and innovation.

1. University-based Ecosystem.

Large scientific and educational organizations often act as initiators and agents of innovation, sources of economic organizations, which seriously affects the pace and quality of regional development. An example of this phenomenon is the University of Porto (Portugal).

Carlos Brito points out three key factors for the success of the University in the development of the ecosystem:

a) the talent to turn the knowledge gained in the scientific and educational process into valuable solutions for companies and other organizations;

b) the potential to establish long-term and relational links between educational institutions and the real sector;

c) integration of a variety of subjects, resources and competencies. A sustainable strategy for innovation and increasing the value of knowledge requires an approach that promotes both internal and external networks [10].

Research shows that scientific organizations and higher education institutions show more ability to achieve diverse and multiple connections with other ecosystem stakeholders. Universities also catalyze international exchange and joint projects. These opportunities and relationships themselves are an illustration to explain the network paradigm, which is used to create achievements in the field of innovation and learning, strengthening cooperation and healthy competition $[12,13]$.

2. Multi-factor ecosystem.

A unique practical multi-subject case is presented by the CaliBaja region [8]. Its peculiarity is that the development of the business ecosystem is implemented on the territory of two States. The CaliBaja innovation ecosystem belongs to Baja California (Mexico) and the state of California (USA). This territory has been recognized as a global innovation megaregion.

Human capital, a territory that combines ocean resources and land biodiversity, contributes to the region's identity. As a result, CaliBaja is a space of opportunity for global businesses operating in sectors such as renewable energy, agribusiness, aerospace and technology, medical device manufacturing, international trade and logistics.

This Binational ecosystem is developed through common efforts and is supported by national, local and bilateral regulatory frameworks. The measures taken make it possible to overcome social, economic, innovation and political asymmetries and achieve a significant level of emergence. Combined institutional efforts, joint public and private measures are implemented in this macroecosystem to ensure economic development through the diffusion of innovation, scientific, technical and educational initiatives.

As an example of interactions, figure 1 shows a part of the CaliBaja ecosystem by industry (bioresources). 


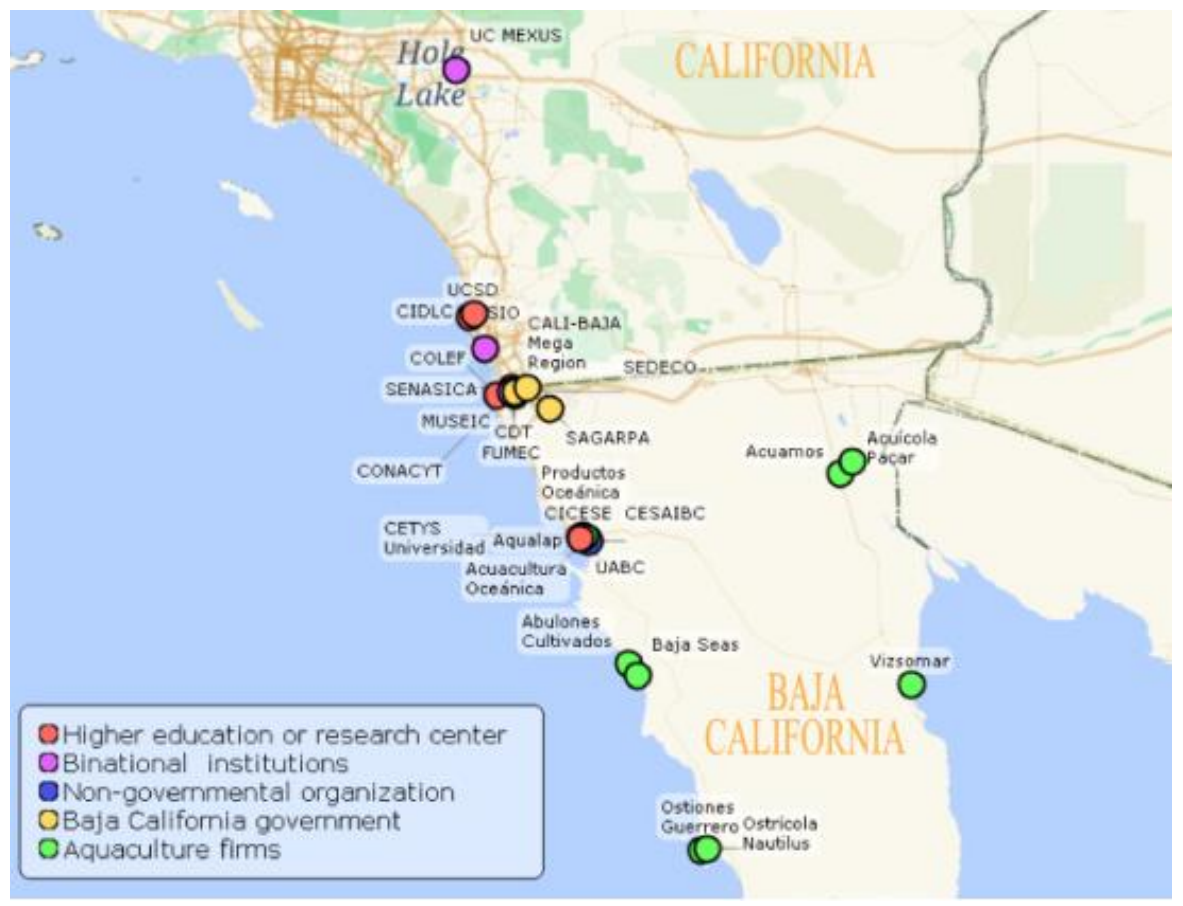

Fig. 1. Stakeholders of the CaliBaja innovation ecosystem (in the aquaculture industry) (Núñez, Serrano-Santoyo, 2020) [8]

3. The Digital ecosystem.

If the previous example reflects rather spatial, territorial connectivity, then the digital platform ecosystem (despite its localization and offline communication in some cases) mainly "exists" in a virtualized field.

A striking example of an innovative digital ecosystem is Silicon Valley (USA), which is home to the world's largest technology corporations, including the headquarters of 39 Fortune 1000 companies and thousands of digital startups. Silicon Valley also accounts for a third of all venture capital investments in the United States, which has helped it become a leading center and startup ecosystem for high-tech innovation and research [14].

Examples of specific platforms within the Valley that implement ecosystem digital dynamics are:

a) Startup Compete, a global network site and competition/collaboration platform based on the global entrepreneurship network. The platform allows aspiring entrepreneurs, mentors, and consultants to connect and develop potential business ideas, bringing them to market;

b) the Google for startups initiative, which offers innovative Google products, a broad network of contacts, and best practices that enable entrepreneurial teams to launch and grow their companies. Gianluca Elia with co-authors writes: «It was in the Valley that the silicon-based integrated circuit, the microprocessor, and the microcomputer, among other technologies, were developed. Silicon Valley is a good example of a self-organizing community or ecosystem of interdependent entrepreneurial agents and companies able to capture technology-based opportunities through the conceptualization, development and launch of novel digital products, solutions and ventures» [14, p.4]. 
Economic modeling of innovative ecosystems depending on key stakeholders allows you to determine the leaders of changes and sources of innovation, channels and networks of interaction, conditions for attracting certain subjects to the ecosystem orbit.

The results of the development of model bases of ecosystems show their diversity and complexity, the ability to expand borders, fill with new system-forming elements, aspects of natural, socio-cultural and economic space. The intersectability and embeddedness of some ecosystems in others indicates the framelessness of ecosystems as a set of sets covering the entire sociosphere. The life force that creates, organizes, and moves forward ecosystems comes from the activity of stakeholders-participants, both for economic purposes (with a focus on profitability) and for social purposes.

The new institutional economic theory identifies three main models of economic activity coordination: firms, markets, and hybrid forms [15]. The question remains debatable: is the innovation ecosystem one of the hybrid forms of institutional coordination, or should it be separated into a separate class? We will leave this issue for further research.

Drawing attention to the real economic life in which ecosystems function, the authors hope that the societal consequences of the active diffusion of the new technological package, called industry 4.0 , will be mitigated by ecosystem vital, antropocentric factors as opposed to mechanistic, technical ones.

In the near future, the world is likely to continue to experience difficulties related to the pandemic, closed borders, and self-isolation, and the need to expand online communication in such conditions will give impetus to the powerful development of digital ecosystems.

This kind of experience can create an environment for purposeful self-restraint in order to achieve sustainable development and reduce environmental harm. It should be remembered that the ecosystem approach in economic relations originates in the ecological concept. Such a dialectic has a chance to synchronize most of the key areas of life to implement an optimistic concept of the future, and provide conditions for preventing and overcoming the consequences of man-made and natural disasters, isolationism, economic stagnation, social and territorial stratification. As a new generation of children of the digital age grows up, platform interactions can lead to global socio-economic changes in management, politics, attitudes to nature and to each other. And the concept of selforganizing communities and innovative ecosystems can provide the necessary transformations of States and people in a peaceful, evolutionary way.

\section{Conclusions}

Based on the results of the research, a hierarchy of models of innovative ecosystems is proposed. It is established that innovative ecosystems are becoming an important class of currently studied economic phenomena.

The following tasks have been solved:

first, the factors that form innovative ecosystems have been identified;

secondly, practical examples of ecosystems are given, illustrating a significant difference in the key conditions for the formation and functioning of the subject under study.

third, the potential socio-economic conditions for the deployment of ecosystems in the future, which require a balanced and responsible attitude to the self-organization of communities, are shown.

The results of the research are proposed to be used for analytical development, design, and description of various examples of the subject under study in the real world, in the activities of socio-economic and political entities located both inside ecosystems and influencing their genesis from the outside. 


\section{Acknowledgements}

The article was supported by the Russian Foundation for Basic Research grant № 20-01000333.

\section{References}

1. H. Lütjen, C. Schultz, F. Tietze, F. Urmetzer, Journal of Business Research, Elsevier, 104 (2019)

2. B. Leten, W. Vanhaverbeke, N. Roijakkers, A. Clerix, J. Van Helleputte, California Management Review, 55(4) (2013)

3. A. Hein, J. Weking, M. Schreieck et al, Electron Markets, 29 (2019)

4. M.G. Jacobides, C. Cennamo, A. Gawer, Strat Mgmt J., 39 (2018)

5. O. Valdez-De-Leon, Technology Innovation Management Review, 9(8) (2019)

6. I.O. Volkova, A.Yu. Yakovleva, Innovations, 10 (228), (in Russian) (2017)

7. M.V. Ciasullo, O. Troisi, M. Grimaldi et al, Int Entrep Manag J., 2 (2020)

8. S.M.P. Núñez, A. Serrano-Santoyo,Technology Innovation Management Review, 10(1) (2020)

9. A.N. Grozin, N.V. Tretyak, H.S. Sarukhanyan, Problems of modern teacher education, 52 (2016)

10. C. Brito, Journal of Innovation Management, 6(3) (2018)

11. L.M. da Silva, C.C. Bitencourt, K. Faccin, T. Iakovleva, Sustainability, MDPI, Open Access Journal, 11(6) (2019)

12. I.V. Korchagina, Corporate governance and innovative development of the economy of the North: Bulletin of the Research Center for Corporate Law, Management and Venture Investment of Syktyvkar State University, 2 (2019)

13. E.V. Popov, A.Yu. Veretennikova, A.A. Safronova, Innovations, 8 (238) (2018)

14. G. Elia, A. Margherita, G. Passiante, Technological Forecasting and Social Change, 150 (2020)

15. O.E. Williamson, Journal of Institutional and Theoretical Economics, 146 (1990) 